\title{
Forage preservation technology for sustainable livestock industry in rainfed areas of Pakistan: A review
}

\author{
Talha Mehmood ${ }^{1 *}$, Zia-Ul-Haq ${ }^{1}$, Saad Mahmood ${ }^{2}$, Muhammad Kazim \\ Nawaz $^{1}$, Hamza Muneer Asam ${ }^{1}$ and Muhammad Kamran Shafi ${ }^{1}$ \\ 1. Faculty of Agricultural Engineering and Technology, PMAS-Arid Agriculture University, Rawalpindi-Pakistan \\ 2. Faculty of Crop and Food Sciences, PMAS-Arid Agriculture University, Rawalpindi-Pakistan \\ *Corresponding author's email: chtalha94@gmail.com \\ Citation \\ Talha Mehmood, Zia-Ul-Haq, Saad Mahmood, Muhammad Kazim Nawaz, Hamza Muneer Asam and Muhammad \\ Kamran Shafi. Forage preservation technology for sustainable livestock industry in rainfed areas of Pakistan: A \\ review. Pure and Applied Biology. Vol. 9, Issue 3, pp1849-1855. http://dx.doi.org/10.19045/bspab.2020.90197
}

\begin{tabular}{llll}
\hline \hline Received: 24/02/2020 & Revised: 27/04/2020 & Accepted: 09/05/2020 & Online First: 00/05/2020
\end{tabular}

\section{Abstract}

Livestock also acts as a bank to meet their daily needs, but the scarcity of quality forage in rainfed agriculture is a limiting factor for livestock. Due to severe shortage of forage, animals remain under-nourished, and thus subject to poor health and productivity. Forages are natural and the cheaper feeding choice for livestock, but their continuous supply in rainfed areas, especially during severe winters (December-January) and summers (May-June), often remains a bottleneck for the development of the livestock industry and hence adequate availability of livestock products in these months. Consequently, prices of livestock products often become high during these months. Silage and hay making using balers is a viable option when plenty of fodder is available in peak season of crop especially in July-August and in February-March.

Keywords: Baler; Forage preservation; Hay; Livestock; Rainfed area; Silage

\section{Introduction}

Livestock plays an integral role in income generation of small farmers to meet day-today emergencies in the rural areas. Farming community maintains livestock in the country for various purposes like milk and meat etc. It not only provides food security by supplying human beings with milk, meat and self-employment, but also plays an important role in alleviating poverty among small-scale farmers. It contributes about 60.5 $\%$ to agriculture products and $11.2 \%$ in Gross Domestic Product (GDP). Livestock recorded a growth of $4.0 \%$ during 2018 as compared to $3.62 \%$ for the same period 2017 [1].

Pakistan has a total livestock population of 201.9 million including buffaloes, cattle, goats, sheep, birds, donkeys, camels, horses, and mules [2]. Livestock populations are increasing day by day and with the passage of time, their quality feed requirements become a challenge. Continuous supply of nutritious fodder in ample quantity is important for growth and productivity of livestock. Fodder crops are essential and cheap GDP source of animal feed. However, shortage of fodder is a key factor that limits livestock production in rainfed areas of Pakistan, particularly in 
Pothwar region. Farmers are quitting farming due to risky farming and resultantly farm number is continuous decreasing. Hence, posing a severe threat to sustainable food supply in rainfed areas of country. Climate change is a global issue that will increase temperature up to $2-6^{\circ} \mathrm{C}$, fluctuations in rainfall and increased occurrence of droughts and floods. These will adversely affect rainfed agriculture. Climate change will also affect agricultural activities resulting in soil erosion [22]. Consequently, availability of feed for livestock in rainfed areas is not uniform throughout the year due to acute fodder shortage owing to harsh weather in severe winter (December-January) and in severe summer (May-June). A common practice is to use wheat straw and sorghum stalks to feed the livestock during lean period in rainfed areas of Pakistan. However, sorghum mature stalks and wheat straw are poor in quality and hence does not provide the required energy for proper animal growth, development and productivity.

A viable option to overcome availability of fodder in slack period is to make silage and hay, in periods of abundant fodder production in peak season of crop. Fodders are the crops that are grown and preserved in the form of silage or hay and fed to animals in a scarcity period when there is shortage of green fodder. Preservation of fodder as silage and hay has helped to stabilize the production of milk and meat which experiences a nosedive during extreme temperatures due to the shortage of green forages. Hay is air-dried fodder, whereas silage is the fermented fodder stored in anaerobic conditions with some additives such as urea and molasses. Crops with thin stems are preferred for hay production as these crops are much easier to shade compared to thick stemmed crops. Legumes like cowpea, guar and soybean having thin stems and are most appropriate for preservation as hay. The thick stemmed crops such as cereal forages are best suited for silage preservation [4, 10, 14, 25-27].

\section{Fodder preservation as silage and hay}

Forage preservation is an important component for a profitable and proficient ruminant livestock development around the world. Forage preservation permits good supply of quality feed when forage production decreases during scarcity period. Moreover, forage preservation gives farmers with an option of storing fodder when production is quicker than can be sufficiently used as pasture. Resultantly, forage preservation offers good quality forage for ruminant animals round the year. Entire plant is dried to make hay, with the goal that it is biologically inactive both with regard to enzyme activity and microbial decay of plant. Low moisture content facilitates easy transportation due to reduced mass per unit of dry matter content. Hay making is a common practice in those areas where good drying conditions are available [23].

Filya et al. [8] reported that ensiled forages are extremely appreciated as animal feed in European nations such as Netherlands, Germany and Denmark. The ensiling method is a preservation under anaerobic condition of moist forage to preserve nutrients. Consequently, $\mathrm{pH}$ will reduce, and wet forage is protected from spoilage of microorganisms. This method is secure and userfriendly; does not pollute the atmosphere; and products are considered natural foods. The preservation of forage as silage bale is made on following well-established method that generally comprises drying of fodder up to $60 \%$ of dry matter content (DM), baling and wrapping of bales with stretched polythene film of 4-6 layers [9]. Scientists observed that silage feeding to cattle is a predominant practice worldwide, and more herbaceous plants are used for silage preparation in developed countries. Ensiling grass-based forage is a primary way to preserve these plants as silage. For small 
farms, silage container stores are sometimes used, and the silage is preserved in large (4-6 $\mathrm{m}^{3}$ ) boxes [30].

Silage preservation technique is attractive to producers owing to several reasons, but the primary advantage is a reduced risk of weather damage to valuable forage crops compared with preservation as dry hay. Most core principles for making high-quality precision-chopped silages also apply to baled silages; among these, establishing and subsequently maintaining an aerobiosis are on priorities basis. Preservation of baled silages can be improved by applying polythene film wraps promptly, using an appropriate number of polythene film 6 to 8 layers, selecting a storage site free of sharp objects or other debris, and by monitoring wrapped bales that are placed closely to avoid puncture, particularly by birds or rats [5].

Silage preparation technique involves harvesting of crop on suitable stage, cutting into pieces and then pressing them tightly. The structures used to make silage are called silos, and these are made of different materials in different shapes and forms. Molasses and urea are used to enhance the rate of fermentation process and to improve silage quality. Lactic acid is produced which determines the quality of the silage by its concentration. Occurrence of oxygen in silos disturbs fermentation process while butyric acid production increases and resultantly silage quality is deteriorated. Excessive heating can cause silage browning resulting in deterioration of silage quality. The best color of good quality silage is from golden to mild brown. The stored fodder as silage gives the lactating animals with excellent quality feed during times of lack of green forage. Sorghum fodder has advantage over maize silage that it can be preserved as silage as well as hay and is the best substitute of maize silage. The fact is that silage production is quite a technical task, since it requires careful calculation of each step from crop harvesting to putting in silos and maintaining anaerobic conditions [15]. Sorghum is an ancient cultivated green forage for milch animals. It is an excellent green forage for ruminant's particularly dairy animals. Sorghum possesses heat and drought tolerance along with its ability withstand soil toxicity have made it a good choice for dairy farmers and forage growers, particularly in tropics [3]. Forage sorghum grown in legumes intercropping systems offers nutritious forage to animals and that is very economically owing to less fertilizer and irrigation usage. Also, forage sorghum can be stored as silage or hay to feed animals during periods of scarcity of green forage. Hence, it is need of hour to optimize the crop potential to ensure a sustainable availability of feed for livestock and eventually human food security.

Human beings have learned to cope with adverse environmental conditions and even to use them for their benefit with the development of science and technology. Forages are the cheapest and most valued feed source of animal and produce excess of green forage when climatic and other conditions are conducive to growth and development. Similarly, during extreme temperature hikes and plunges, forage become deficient and ultimately lactating animals are underfed [17]. The net result is a sharp decline in the production of milk and meat which compromises human food safety. Therefore, sustainable forage production goes a long way towards ensuring animal nutrition and eventually human food safety. To ensure the sustainable availability of forages to milch livestock even during temperature extremes, silage and hay making techniques were established which may be declared as the top discoveries of the century as far as dairy science is concerned [16]. Animal feed is one of the main costs of producing livestock [18]. In Brazil, the 
tropical climate favors the production of forages, the use of which usually costs less than concentrated ingredients (corn and soybean meal) and is therefore always used in ruminant diets in large amounts, frequently over $40 \%[24,31]$. The use of forage plants adapted to the area, along with the practice of ensiling, increases the allowance for forage, especially during the year's dry season, and can make sheep farming a sustainable task. According to Cowan, [7] ensiling is an important practice that permits for better use as a dry-period reserve of the surplus forage produced in the rainy season.

Employment generation in the business of bales making is gaining a considerable momentum in the agricultural and industrial area due to mechanization of its production chain, the ease of their manipulation and transportation, flexibility of storage and the less manpower requirements [12]. Storage and transportation are two essential operations of biomass supply chain in bailing as during transport of forage through use of specific vehicles, large areas are needed for storage purpose.

\section{Baling methods}

Huhnke et al. [13] revealed that several wrapping bale methods are accessible: wrap stretch plastic on single rectangular and round bales or round big bales arranged from end to end, either in a wrapped with stretch plastic wrap or plastic tube. These last options decrease the plastic used, significantly improve the productivity of wrapping and decrease storage area compared to separately wrapped bales. Moreover, tube line wrapping can decrease flexibility of feeding paralleled to separate wrapping of bales. Preservation of huge amount of fodder as silage in the form of wrapped bales is a convenient method in most of the countries and is appealing to the producers [34] so it gives benefits compared to hay production, such as a more flexibility in harvest date, less dependency on weather, and more flexibility in ration making $[6,28$, 29].

\section{Round baler}

A round baling machine (Orkel MP2000) is widely used in agriculture and industry area to compress biomass. Baler was used for baling urban waste in the industrial area as well as for wrapping silage in the agricultural area. The optimum quantity of material is fed to the compaction chamber assisted by the advanced and reliable sensor system. The wrapping is done in parallel with the baling. The prepared bales are carefully placed on the ground, once they have been wrapped with plastic sheet. The machine was powered by a 110 kilowatt $(\mathrm{kW})$ nominal power tractor during the test. After bailing a $43 \%$ volume decreased with respect to the piled chips loose bulk density. The productivity of the fresh (green) wood chips ranged from $19.8 \mathrm{t} / \mathrm{h}$ to $21.7 \mathrm{t} / \mathrm{h}[20]$.

\section{Rectangular baler}

Large rectangular balers, usually used for hay baling, vary greatly according to their feeding mechanism. The Scientists found that large square baler with a pre-compression chamber provided the best shaped and densest red canary grass bales [19]. In many developing countries, straw collection was always dependent on a handful of elderly stationary balers with top-feed ram stroke and wire / plastic twine tie design, and straw was shipped in rectangular bales such as $0.6 \times 0.5 \times 1.5 \mathrm{~m}^{3}$ (width, height and length). Length of the bale varied till $1.9 \mathrm{~m}$. Mass was usually $100-120 \mathrm{~kg} / \mathrm{bale}$, but could be higher, which make this baling system classified as medium to large baling system. The small straw bale presser is developed by small-sized iron factories of the local private sector. Metal string or plastic ropes can be used to tie the straw bale, the baler move from place to place near the field to bale manually collected rice straw [11].

Steele et al. [32] reported that mobile straw baling powered machines came later and now 
are commonly used in North Africa region, the first baler for mass production was smaller in size and particularly appropriate for harvesting of straw from small areas, and small producers made the bale conveniently and easy to handle. It is mostly used by the governmental straw collection centres that provide farmers with straw baling facilities. This type of baler was used only for rice straw in hay form. These balers produced small rectangular bales with dimensions 0.80 $\times 0.46 \times 0.36 \mathrm{~m}^{3}$ with mass up to $25 \mathrm{~kg}$. These types of rectangular balers are now produced locally in some countries e.g. like in Egypt under licence to foreign Italian manufacturer. Another scientist found that movable straw baler was designed and manufactured during 2003 and altered during 2004 at the Agricultural Mechanization Research Institute (AMRI), Multan, Pakistan. The field performance of this baler was evaluated in 2009. This movable straw baler's design parameters were based on local farm size, crop waste and field situations. In 2003, AMRI's workshop manufactured the first prototype of movable straw baler using locally accessible materials and facilities. Some important components and parts such as gears, hydraulic jack and hydraulic pump were manufactured by the local industry in accordance with their technical specifications [35].

Researcher revealed that in Ghana, the rectangular balers are used now in some places for baling rice straw mainly as cattle feed. However, no local manufacturing or assembling operations running within the country, all available balers are imported [21]. In rectangular baler, bale chamber pressure, besides varying forward speeds and windrow sizes, is the most important parameter affecting the bale density. Some research studies that baling very hard and coarse material in round baling. However, many studies consider silage baling, where the material is relatively softer having more moisture content (40-75\%). Bale weight, density and nutrient content are the very imperative factor characterizing the shaped hay bales [33].

\section{Conclusion}

Livestock in Pakistan continue to suffer from malnutrition particularly during May-June and December-January during which shortage of green forage affect animal health along with productivity. It is imperative to develop fodder preservation technologies to support dairy farmers. Awareness about importance of these technologies to ensure sustainable fodder supply to minimize decline in animal health. Hay and silage making techniques are of most importance as the milk yield in Pakistan is very less as compared to number of animals and their potential. Therefore, excessive forage stored as silage and hay guarantees to increase milk and meat production and also improve the socio-economic status of dairy farmer.

\section{Authors' contributions}

Contributed in the preparation of manuscript: T Mehmood, ZU Haq, S Mahmood, MK Nawaz, HM Asam \& MK Shafi, Wrote the paper: Talha Mehmood and Saad Mahmood.

\section{References}

1. Anonymous (2018). Economic Survey of Pakistan. Government of Pakistan, Finance Division, Economic Advisory Wing, Islamabad, pp. 503.

2. Anonymous (2018). Livestock Census Punjab. Livestock and Dairy Development Department, Punjab Civil Secretariat, Lahore, pp. 36.

3. Ayub M, Tanveer A, Nadeem MA \& Shah SMA (2004). Studies on the fodder yield and quality of sorghum grown alone and in mixture with rice bean. Pak J life Soc Sci 2(1): 46-48.

4. Baloyi JJ, Ngongoni NT \& Hamudikuwanda H (2008). Chemical composition and ruminal degradability of cowpea and silver leaf desmodium forage legumes harvested at different 
stages of maturity. Trop Subtrop Agroecosyst 8: 81-91.

5. Coblentz WK \& Akins MS (2018). Silage review: Recent advances and future technologies for baled silages. $J$ Dairy Sci 101: 4075-4092.

6. Coblentz WK, Coffey KP \& Chow EA (2016). Storage characteristics, nutritive value, and fermentation characteristics of alfalfa packaged in large-round bales and wrapped in stretch film after extended time delays. J Dairy Sci 99: 3497-3511.

7. Cowan T (2000). Uso de forrajes ensilados en sistemas de producción animal de gran escala. In: Mannetje, L. (Ed.), Uso del ensilaje en el trópico privilegiando opciones para pequeños campesinos. FAO, Roma, pp. 31-40.

8. Filya I, Ashbell G, Hen Y \& Weinberg ZG (2000). The effect of bacterial inoculants on the fermentation and aerobic stability of whole crop wheat silage. Anim Feed Sci Tech 88: 39-46.

9. Forristal PD \& Kiely PO (2005). Update on technologies for producing and feeding silage. In R. S. Park, \& M. D. Stronge (Eds.), Proceedings 14th International silage Conference pp. 8396.

10. Gebreyowhans S \& Gebremeskel K (2014). Forage production potential and nutritive value of cowpea (Vigna unguiculata) genotypes in the northern lowlands of Ethiopia. J Agric Res Dev 5(4): 66-71.

11. Garas GL, Allam ME, El Kady HM \& El Alfy AH (2009). Compressibility of single un-rendered rice straw bales: Characteristics of bales used for building. ARPN J Engg Appl Sci 4(5): 64-90.

12. Guerrieri AS, Anifantis AS, Santoro F \& Pascuzzi S (2019). Study of a large square baler with innovative technological systems that optimize the baling effectiveness. Agric 9(86). doi:10.3390/agriculture9050086

13. Huhnke RL, Muck RE \& Payton ME (1997). Silage bale storage losses of ryegrass and legume-grass forages. Appl Engg Agric 13: 451-457.

14. Iqbal A, Ayub M, Zaman H \& Ahmad R (2006). Impact of nutrient management and legume association on forage qualitative traits of maize forage. Pak $J$ Bot 38: 1079-1084.

15. Iqbal MA \& Iqbal A (2015). Overviewing forage shortage for dairy animals and suitability of forage sorghum for ensiling. Global Veter 14(2): 173-177.

16. Ibrahim MNM (1983). Physical, chemical, physico-chemical and biological treatments of crop residues. In: Pearce, G.R. (ed.), The Utilization of Fibrous Agricultural Residues. Research for Development Seminar Three, 19-23 May 1981, Australian Development Assistance Bureau (ADAB), Los Baños, The Philippines and Australian Government Publishing Service, Canberra, pp 53-68.

17. Khan MJ, Abbas A, Naeem M, Ayaz MM \& Akhter S (2013). Current issues and future prospects of dairy sector in Pakistan. Sci Tech Dev 32(2): 126-139.

18. Khan MI, Jo C \& Tariq MR (2015). Meat flavor precursors and factors influencing flavor precursors - a systematic review. Meat Sci 110: 278-284.

19. Lotjonen $\mathrm{T} \&$ \& Paappanaen $\mathrm{T}$ (2013). Bale density of red canary grass spring harvest, Biomass \& Bioenergy 51: 53-59.

20. Manzone M (2015). Efficiency of a compactor in wood chip volume reduction. Biomass \& Bioenergy 80: 303-306.

21. Mofa (2013). The Ministry of Food and Agriculture, GHANA, accessed on April, 2013. http://mofa.gov.gh/site/?page_id=4145. 
22. Mercer KL \& Perales HR (2010). Evolutionary response of landraces to climate change in centers of crop diversity. Evol Appl 3(5-6): 480-93.

23. Muck RE \& Shinners KJ (2001). Conserved Forage (Silage and Hay): Progress and Priorities, International Grassland Congress, 19, Piracicaba.

24. Nicory IMC, Carvalho GGP, Ribeiro OL, Santos SA, Silva FF, Silva RR, Lopes LSC, Souza FNC \& Freitas JE (2015). Productive and metabolic parameters in lambs fed diets with castor seed meal. Livestock Sci 181: 171-178.

25. Odion EC, Asiribo OE, Ogunlela VB, Singh BB \& Tarawali SA (2007). Strategies to improve and sustain food production capacity in the savanna: The role of leguminous fodder crops in maintaining soil fertility and health. $J$ Food Agric Envir 5: 338-344.

26. Rao NK \& Shahid M (2011). Potential of cowpea (Vigna unguiculata (L.) Walp.) and guar (Cyamopsis tetragonoloba (L.) Taub.) as alternative forage legumes for the United Arab Emirates. Emir J Food Agric 23(2): 147-156.

27. Singh BB, Ajeigbe HA, Tarawali SA, Fernandez RS \& Abubakar M (2003). Improving the production and utilization of cowpea as food and fodder. Field Crops Res 84: 169-177.

28. Savoie P \& Jofriet JC (2003). Silage storage. In DR Buxton, RE Muck, \& JH Harrison (Eds.), Silage science and technology. Agron Monogr 42: 405-467.

29. Shinners KJ, Huenink BM, Muck RE \& Albrecht KA (2009). Storage characteristics of large round and square alfalfa bales: low-moisture silage bales. Transac ASABE 52(2): 401-407.

30. Sirvydis J \& Dravininkas A (2005). Artificially dried grass forage technology basics: Monograph. Raudondvaris, pp. 230.

31. Silva RVMM, Carvalho GGP, Pires AJV, Pereira MLA, Pereira L, Campos FS, Perazzo AF, Araújo MLGML, Nascimento CO, Santos SA, Tosto MSL, Rufino LMA \& Carvalho BMA (2016). Cottonseed cake in substitution of soybean meal in diets for finishing lambs. Small Rumin Res 137: 183-188.

32. Steele P, El-Hissewy A \& Badawi A (2009). Technical manual: Agroindustrial use of rice straw project. Rural Infrastructure and Agro-industries Division, Food and Agriculture Organization of the United Nations, Regional Office for the Near East, Cairo, Egypt. ISBN: 978-977-302258-2.

33. Sun Y, Cheng Q, Meng F, Buescher W, Maack C, Ross F \& Lin J (2012). Imagebased comparison between a $\gamma$-ray scanner and a dual-sensor penetrometer technique for visual assessment of bale density distribution. Comp Electro Agric 82: 1-7.

34. Wilkinson JM \& Toivonen MI (2003). World silage. Welton, Lincoln UK: Chalcombe Publications.

35. Yasin M (2012). Performance evaluation of mobile straw baler. J Agric Res 50(2): 261-270. 